\title{
PERANCANGAN SISTEM PEMELIHARAAN DATABASE BANGUNAN DI DINAS PERUMAHAN DAN PERMUKIMAN KOTA BOGOR
}

\author{
Rita Komalasari,S.Si.,M.Kom \\ Dosen Prodi Manajemen Informatika \\ Politeknik LP3I Bandung \\ Email: ritakomalasari123456@gmail.com
}

\begin{abstract}
Abstrak: Dinas Perumahan dan Permukiman melaksanakan pengawasan dan pengendalian baik terhadap seluruh penyelenggaraan bangunan di Kota Bogor pada khususnya maupun pemanfaatan ruang pada umumnya. Dinas Perumahan dan Permukiman Kota Bogor telah memiliki Sistem Informasi Database Bangunan yang telah terbangun pada tahun 2013. Untuk mengupdate data bangunan secara periodik diperlukan kegiatan yang dikhususkan untuk pemeliharaan database bangunan tersebut sehingga dapat dilakukan kegiatan verifikasi data bangunan yang sudah ada pada Sistem Informasi Database Bangunan melalui Survey Lapangan dan Input Database Bangunan Gedung secara spasial dan mengembangkan sistem informasi database bangunan dalam hal updating menu -menu pada sistem yang belum terakomodir untuk akses ke data bangunan.
\end{abstract}

Kata Kunci: Database, Sistem Informasi, Data Bangunan Gedung

\section{Pendahuluan}

\subsection{Latar Belakang Masalah}

Bangunan gedung yang merupakan aset milik Pemerintah Kota Bogor sangat banyak dan tersebar di 6 (enam) kecamatan. Diperlukan suatu informasi sistem database bangunan gedung milik Pemerintah Kota Bogor yang memiliki ketersediaan dan aksesibilitas informasi yang cepat dan akurat mengenai data historis bangunan gedung, lokasi beserta kondisi terkini yang sesuai dengan keadaan sebenarnya di lapangan.

Sistem informasi database bangunan gedung sudah menjadi suatu kebutuhan untuk menunjang informasi dan untuk menunjang perencanaan yang cepat, tepat dan akurat karena kualitas suatu perencanaan yang baik sangat membutuhkan ketersediaan dan aksessibilitas informasi yang cepat dan akurat.

Menurut Peraturan Daerah Kota Bogor Nomor 7 Tahun 2006 Tentang Bangunan Gedung, bangunan gedung adalah wujud fisik hasil pekerjaan konstruksi yang menyatu dengan tempat kedudukannya, sebagian atau seluruhnya berada di atas dan/atau di dalam tanah dan/atau air, yang berfungsi sebagai tempat manusia melakukan kegiatannya, baik untuk hunian atau tempat tinggal, kegiatan keagamaan, kegiatan usaha, kegiatan sosial, kegiatan budaya, maupun kegiatan khusus.

Pendataan bangunan gedung dilakukan oleh pemerintah kabupaten/kota, kecuali Provinsi DKI Jakarta. Hasil pendataan bangunan gedung dapat dimanfaatkan oleh pemerintah daerah atau masyarakat melalui suatu sistem informasi bangunan gedung. 


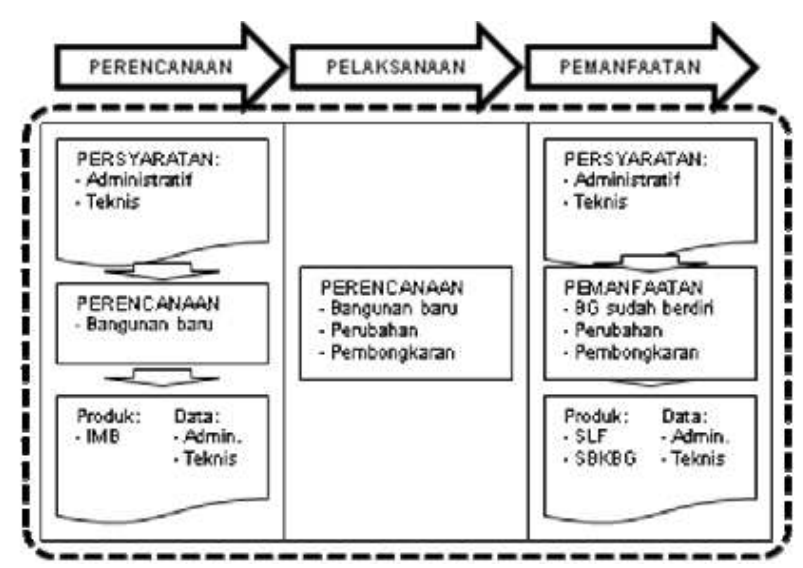

Gambar 1. Konsep Pendataan Bangunan Gedung dilihat dari proses pentahapannya

Pada saat pendataan bangunan gedung baik pada tahap Permohonan Perubahan Izin Mendirikan Bangunan Gedung PPIMB ataupun Sertifikat Laik Fungsi (SLF) dilakukan proses updating database atau pemutakhiran data sehingga diperoleh data yang baru suatu bangunan gedung.

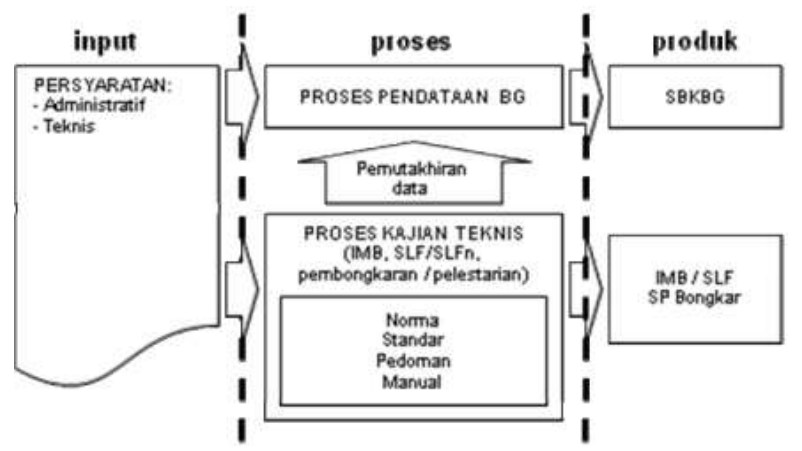

Gambar 2. Konsep Proses Pendataan Bangunan Gedung dalam kegiatan administrasi BG

Tujuan kegiatan ini adalah untuk memelihara dan menyediakan data melalui sistem informasi pengawasan dan pengendalian bangunan yang memuat :

1. Data kepemilikan, penggunaan, pemanfaatan bangunan gedung dan tanah.

2. Data hasil pengawasan bangunan

Sasaran kegiatan Pemeliharaan database bangunan gedung adalah :

1. Tersedianya pengembangan sistem informasi pengawasan dan pengendalian bangunan gedung di Kota B

2. Tersedianya informasi/data bangunan gedung sesuai dengan format Peraturan Menteri Pekerjaan Umum Nomor 17/PRT/M/2010 tentang Pedoman Teknis Pendataan Bangunan Gedung di Kota Bogor

Pelaksanaan kegiatan Pemeliharaan database bangunan gedung ini diharapkan dapat memberikan manfaat sebagai berikut :

1. Meningkatkan kualitas kinerja operasional pengawasan dan pengendalian bangunan di Kota B sehingga terwujud tertib penyelenggaraan bangunan sesuai amanat Peraturan Daerah Kota Bogor Nomor 7 Tahun 2006 tentang Bangunan 
Gedung dan Peraturan Daerah Kota Bogor dan Nomor 8 Tahun 2011 tentang RTRW Kota Bogor 2011-2031.

2. Memberikan kemudahan untuk mengakses data/informasi terkait penyelenggaraan bangunan gedung di Kota B baik oleh pihak internal maupun eksternal

\section{Tinjauan Pustaka}

\subsection{Dasar Hukum}

Dalam rangka implementasi Pemeliharaan dan Updating Data base Bangunan Gedung telah disusun sejumlah peraturan yang berperan dalam kegiatan ini. Kebijakan tersebut merupakan rencana dan kebijakan yang diambil oleh pemerintah untuk mewujudkan penyimpanan arsip yang optimal. Berikut ini akan dijelaskan lebih lanjut mengenai produk-produk kebijakan mengenai arsip yang berlaku.

Peraturan perundang-undangan yang terkait dengan Pemeliharaan dan Updating Data base Bangunan Gedung adalah sebagai berikut:

1. Peraturan Menteri Pekerjaan Umum Nomor 17/PRT/M/2010 tentang Pedoman Teknis Pendataan Bangunan Gedung di Kota Bogor

Peraturan Daerah Kota Bogor Nomor 7 Tahun 2006 tentang Bangunan Gedung dan Peraturan Daerah Kota Bogor

2. Peraturan Daerah Kota Bogor Nomor 8 Tahun 2011 tentang RTRW Kota Bogor 2011-2031.

\section{2..2 Ruang lingkup Pemeliharaan dan Updating Database Bangunan Gedung}

Uraian berikut ini meliputi penjelasan kegiatan Pemeliharaan dan Updating Database Bangunan Gedung.

1. Analisa desain program database bangunan dan peningkatan sistem informasi sesuai kebutuhan pihak kesatu (pengguna jasa)

2. Pengolahan Data Bangunan

Pengolahan data bangunan merupakan kegiatan memasukkan data lokasi bangunan pada satu wilayah kelurahan (koordinat titik lokasi) berdasarkan data primer hasil survey yang dilaksanakan oleh Dinas Perumahan dan Permukiman ke dalam program Sistem Informasi Tata Ruang

3. Pengolahan data Pengawasan Bangunan

Pengolahan data pengawasan bangunan merupakan kegiatan memasukkan data hasil pengawasan bangunan ke dalam Sistem Informasi Database Bangunan Gedung dan Sistem Informasi Tata Ruang

4. Pelaporan

Penyedia jasa wajib menyusun laporan pendahuluan yang berisi rencana kerja, laporan antara yang berisi laporan kemajuan hasil pekerjaan dan laporan akhir yang berisi laporan keseluruhan hasil pekerjaan.

\subsection{Metode Updating Database Bangunan Gedung}

Sistem yang digunakan dalam pendataan bangunan gedung merupakan sistem terkomputerisasi.

Sistem pendataan bangunan gedung ini merupakan bagian yang tidak terpisahkan dalam seluruh tahapan penyelenggaraan bangunan gedung sehingga aplikasi yang digunakan di arahkan untuk dapat dimanfaatkan pada seluruh alur kerja dalam tata kelola bangunan 
gedung yaitu meliputi tahap perencanaan, pelaksanaan, dan pemanfaatan serta pembongkaran.

Sebagai bagian utama dalam sistem pendataan bangunan gedung antara lain:

Bagian yang paling utama dalam sistem ini adalah

a. Database

Fungsi database ini adalah sebagai tempat penyimpanan data yang direncanakan dapat memberikan kemudahan pada saat dibutuhkan informasi yang ada di dalamnya.

Dalam sistem pendataan bangunan gedung akan memiliki beberapa tabel data yang saling berhubungan satu dengan yang lain atau disebut "Relational database".

b. Formulir data, Pertanyaan (queries), Laporan (Report)

Merupakan bagian lain yang terpisah dari database namun dihubungkan dengan sistem pengaksesan sehingga menjadi suatu sistem yang saling berhubungan bangian lain tersebut adalah:

a. Formulir pendataan bangunan gedung (input) digunakan untuk memasukan data yang belum ada sebelumnya dan updating data yang telah ada,

b. Pertanyaan / queries pendataan bangunan gedung digunakan untuk fungsi pengambilan informasi dari data yang sudah tersimpan dalam data base.

c. Format laporan/report pendataan bangunan gedung (output) digunakan pada saat diperlukan pembuatan laporan dari hasil pendataan yang sudah terkumpul selama ini.

Pemasukan data pada kegiatan pendataan bangunan gedung terdiri dari dua bagian

1. Data baru yaitu pada saat bangunan gedu ng baru di data, disertai lampiran -lampiran dokumen awal dari bangunan gedung, yang terdiri dari data administrasi dan data teknis bangunan gedung (IMB).

2. Updating data yaitu pemutakhiran dari data suatu bangunan gedung yang sudah didata sebelumnya, serta dilengkapi dengan dokumen-dokumen lampiran yang baru (PPIMB).

Misal : Suatu bangunan gedung mengalami perubahan dari perencanaan awal dari segi bentuk, fungsinya serta bila terjadi perubahan kepemilikan ataupun pengelolanya.

Hal ini dimaksudkan agar dokumen-dokumen yang sudah masuk dapat dibuat data yang lebih jelas dalam setiap tahapannya, yaitu (1) tahap pengajuan, (2) tahap proses, tahap akhir/hasil. Demikian juga pemilik/pengelola bangunan akan lebih mudah untuk mengetahui sampai dimana proses perizinan bangunan gedungnya.
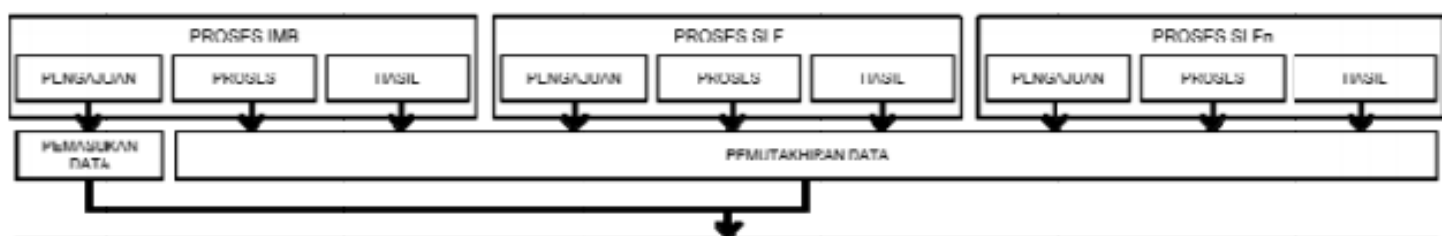

DNTNONSC aNNGUNMN GCOUNG

Gambar 3. Alur pemasukan data berdasarkan pentahapannya

\subsection{Metodologi Kegiatan Secara keseluruhan}

Seluruh dasar dari pekerjaan kegiatan pemeliharaan dan updating data base bangunan gedung ini senantiasa mengacu pada KAK yang sudah ditetapkan. Metodologi pekerjaan 
kegiatan pemeliharaan dan updating data base bangunan gedung secara keseluruhan dapat dilihat pada gambar 4, yang terdiri dari

1. Kerangka Acuan Kerja Pemahaman latar belakang dan tujuan dari pekerjaan kegiatan pemeliharaan dan updating data base bangunan gedung

2. Metodologi Pelaksanaan Pekerjaan

Penentuan tahapan pekerjaan yang dilakukan secara keseluruhan baik proses kegiatan pemeliharaan dan updating data base bangunan gedung maupun maupun pembuatan laporan kegiatan yang akan diekspose kepada user

3. Evaluasi studi literatur

Pemahaman aturan-aturan yang berlaku pada pekerjaan kegiatan pemeliharaan dan updating data base bangunan gedung, seperti aturan kepemilikan, penggunaan, pemanfaatan serta riwayat bangunan gedung dan tanah termasuk kesesuaian antara penggunaan bangunan gedung dengan rencana tata ruang wilayahnya.

4. Identifikasi dan Pemeliharaan database bangunan gedung Eksisting Pemahaman tentang sistem informasi database bangunan gedung yang sudah dikembangkan sebelumnya, seperti struktur tabel database, struktur data, dan RDBMS (software tempat menyimpan data) yang digunakan.

5. Evaluasi metodologi kegiatan proses pemeliharaan dan updating data base bangunan gedung

Penentuan tahapan-tahapan yang dilakukan pada proses pemeliharaan dan updating data base bangunan gedung, yang terdiri dari

a. Pengumpulan data dokumen bangunan gedung

b. Update data bangunan gedung pada database sementara

c. Update data pada database (penggabungan data)

6. Pembuatan laporan pendahuluan, laporan antara dan laporan akhir 


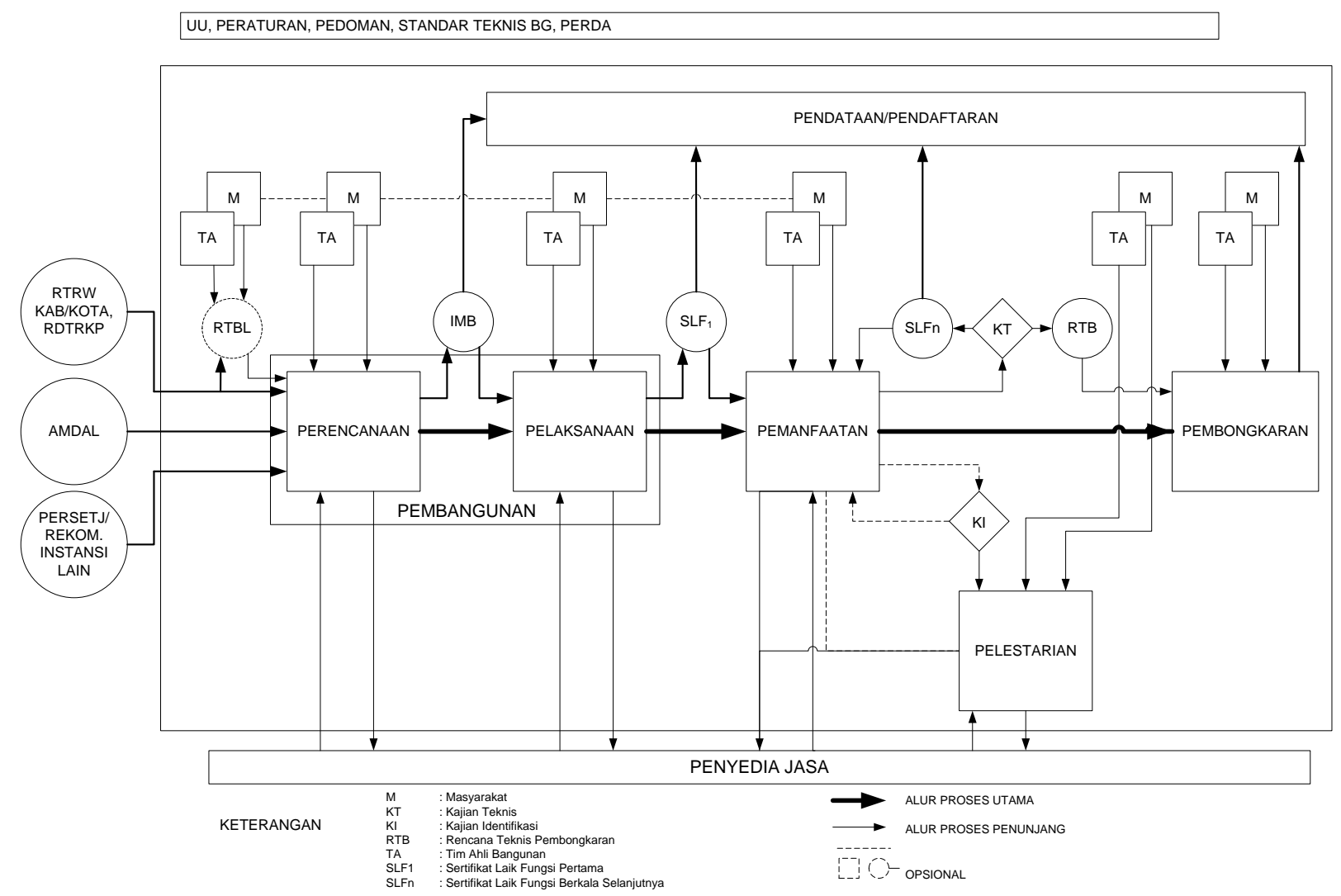

Gambar 4. Penyelenggaraan pendataan bangunan gedung

\section{Pengumpulan data}

Pendataan database bangunan gedung yang telah terkumpul di 6 kecamatan melalui kegiatan Penyusunan Database Bangunan Gedung tahun 2013-2014 ke dalam sistem informasi database bangunan gedung yang sudah dikembangkan.

Adapun dokumen yang dijadikan sumber data dalam kegiatan pemeliharaan dan updating data base bangunan gedung ini :

1. Surat permohonan;

2. isian formulir lengkap \& photo lapangan;

3. Hak atas tanah;

4. Gambar Perencanaan (terkait proses IMB)

5. As build drawing (terkait proses SLF);

6. Perizinan;

\section{Update data bangunan gedung pada database}

Berdasarkan database bangunan gedung yang telah terkumpul di 6 kecamatan melalui kegiatan Penyusunan Database Bangunan Gedung tahun 2013-2014 kemudian akan dilakukan update data ke dalam sistem informasi database bangunan gedung yang sudah dikembangkan.

Struktur database dan struktur data disesuaikan dengan struktur database dan struktur data yang sistem informasi tata ruang yang dimiliki Dinas Perumahan dan Permukiman.

Adapun struktur dari database yang dibuat dapat dilihat pada gambar 5 


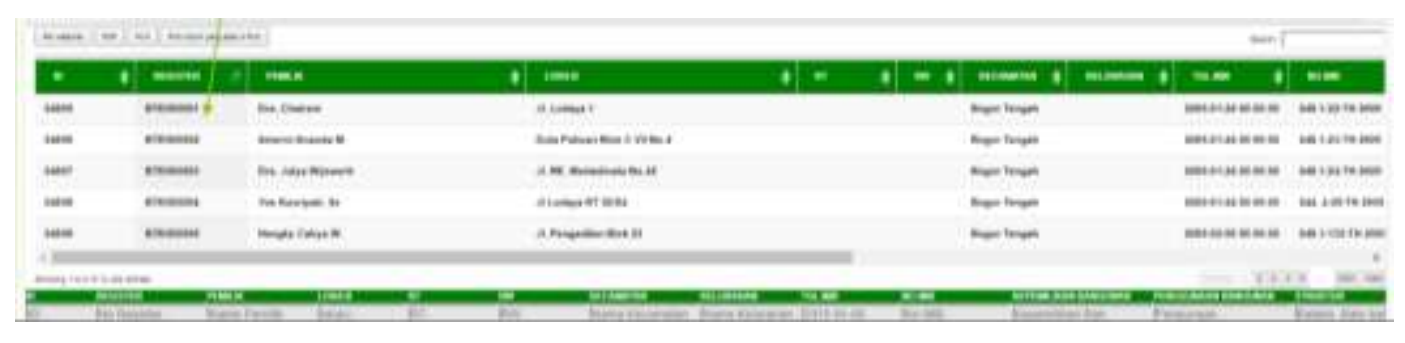

Gambar 5. Proses update Database bangunan gedung

\section{Perancangan Pemeliharaan dan Updating data base Bangunan gedung}

Pada tahap perencanaan updating pada database bangunan gedung dilakukan per kecamatan.

1. Bogor Barat

2. Bogor Selatan

3. Bogor Tengah

4. Bogor Timur

5. Bogor Utara

6. Tanah Sareal

Gambar dibawah ini memperlihatkan proses perencanaan updating data base bangunan gedung pada pembuatan web Pendataan bangunan.

Pada Menu Utama terdapat 3 Sub Menu :

1. Lokasi Bangunan

2. Tabel Data Bangunan
a. Bogor Tengah
b. Bogor Timur
c. Bogor Barat
d. Bogor Utara
e. Bogor Selatan
f. Tanah Sareal

3. Tabel Monitoring
a. Tabel Pendataan Bogor Barat
b. Tabel Pendataan Bogor Selatan
c. Tabel Pendataan Bogor Tengah

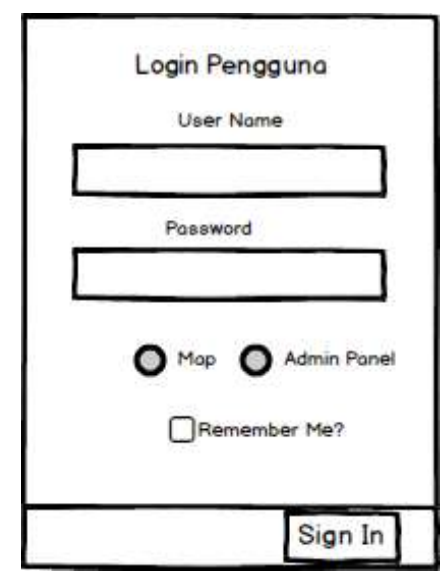

Gambar 6. Perancangan Login User pada aplikasi web 


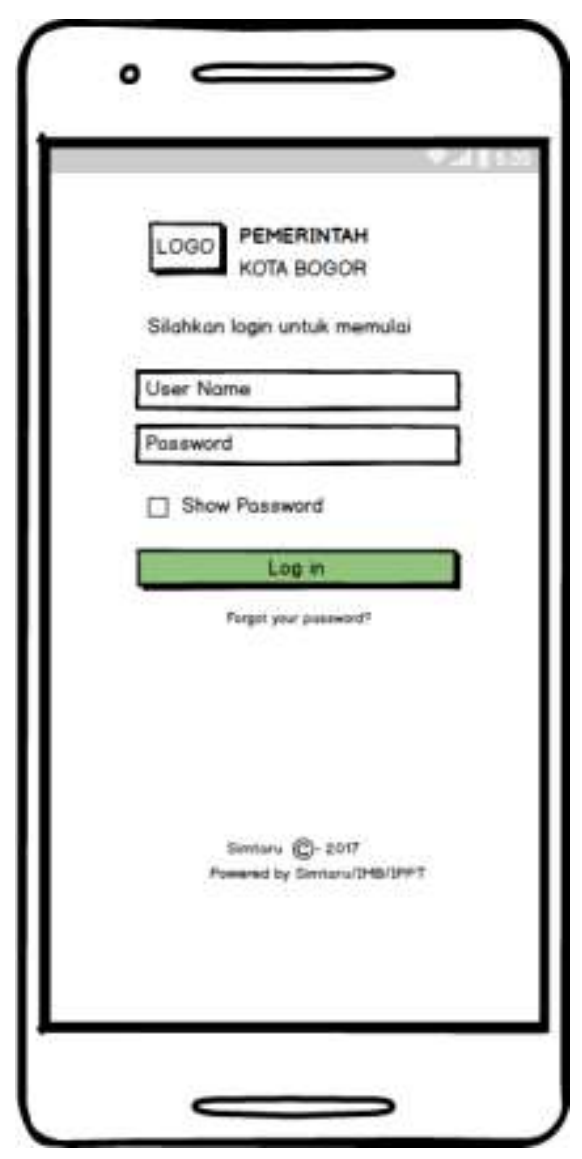

Gambar 6. Perancangan Login User pada aplikasi Android
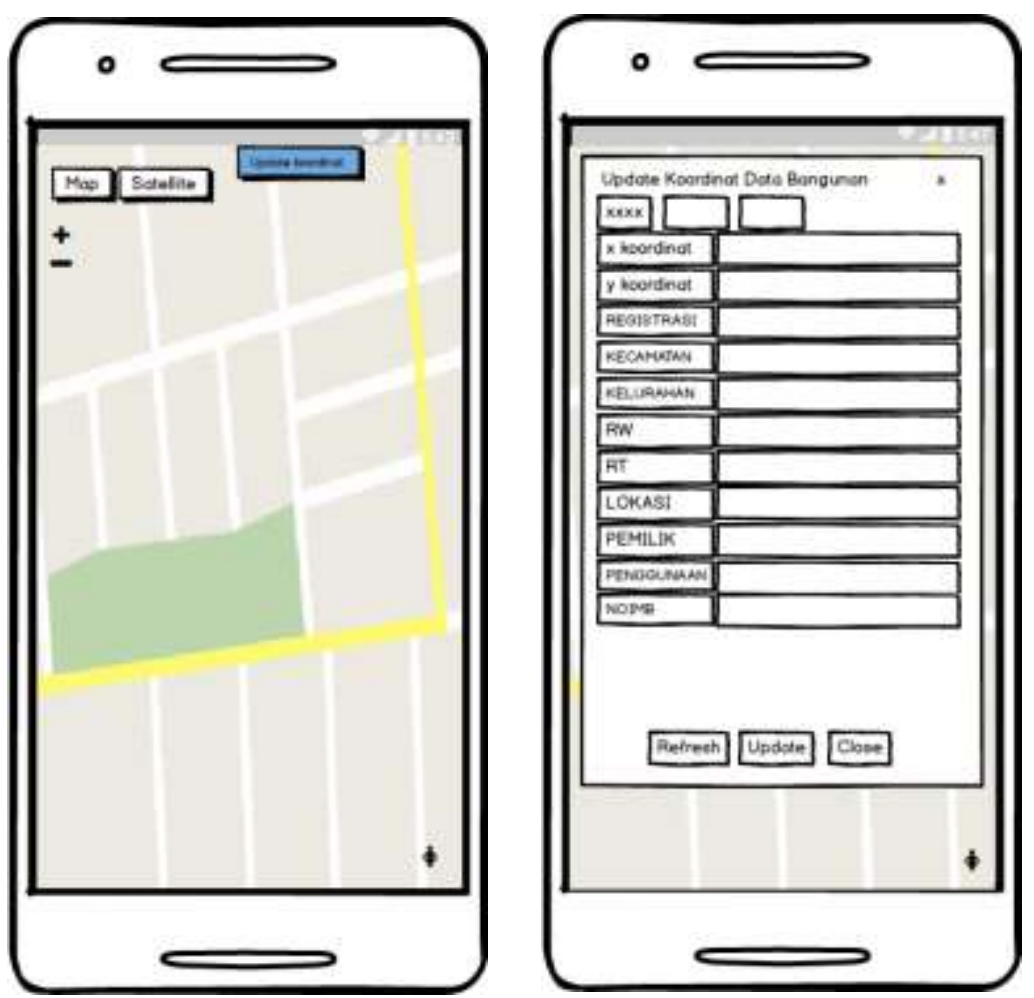

Gambar 7. Perancangan aplikasi android Pendataan - Bangunan 
Pada aplikasi berbasis Mobile terdapat fitur sebagai berikut :

1. Tombol Pencarian Data

2. Informasi Lokasi User/Surveyor di lapangan

3. Form isian pencarian data bangunan dari database

4. Tombol Penyimpanan data koordinat Lapangan

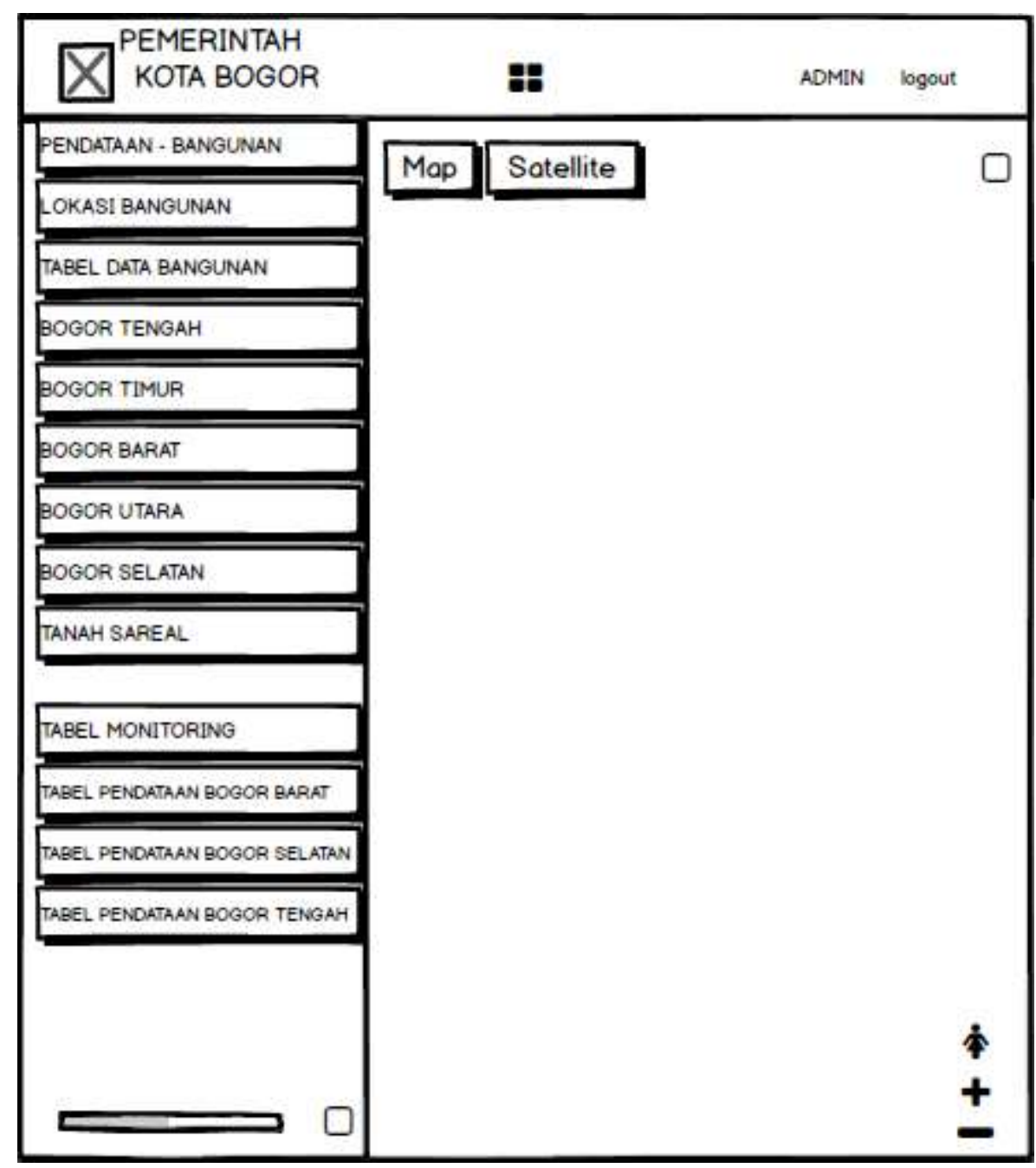

Gambar 8. Perancangan Web Pendataan - Bangunan

Menu LOGIN digunakan oleh Tampilan Menu Pengguna dan Manajemen Aplikasi UPDATING DATA BANGUNAN :

Isi Username dan Password yang sudah didaftar sebelumnya.

Aplikasi updating database bangunan gedung dapat diakses melalui 2 cara :

1. Komputer : digunakan untuk melakukan monitoring data bangunan

2. Tablet $(\mathrm{Hp})$ : digunakan untuk melakukan updating kordinat lokasi bangunan

\section{Implementasi Pemeliharaan dan Updating data base Bangunan gedung}

Aplikasi database bangunan gedung merupakan aplikasi Web/Android yang terhubung dengan komputer jaringan lokal atau internet dan hanya memerlukan browser untuk dapat menjalankannya. 


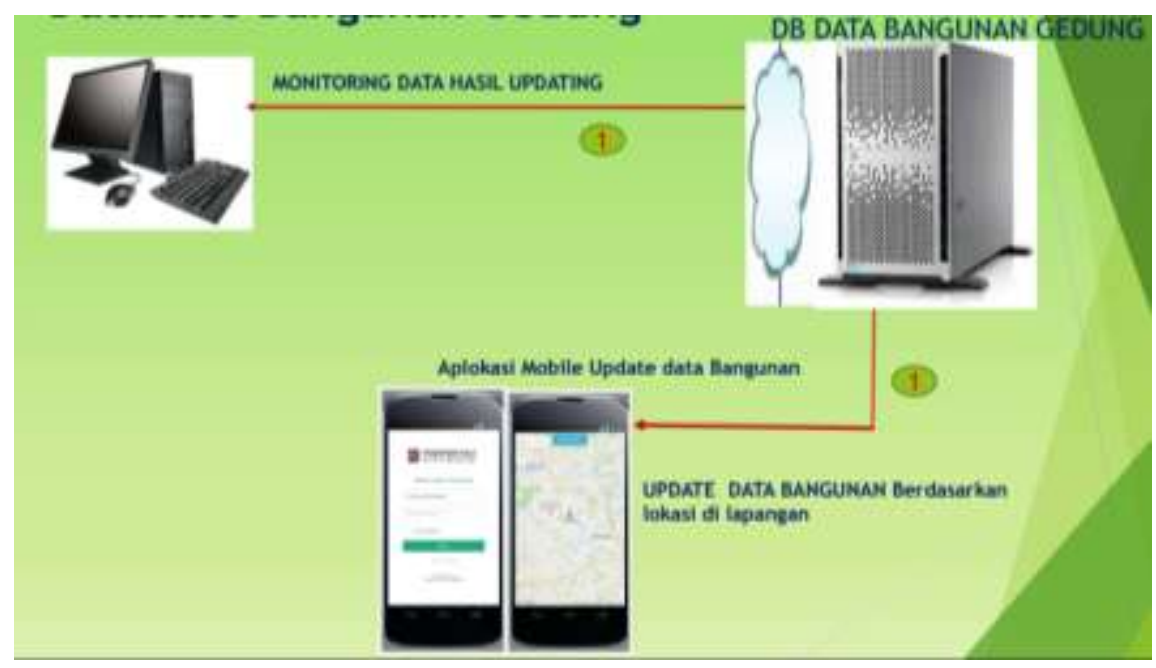

Gambar 9. Database bangunan gedung yang terhubung dengan perangkat mobile

Prosedur tata cara penggunaan aplikasi ini dimulai dengan munculnya layar pembuka dengan menu halaman Login yang terdiri dari "User Name" dan "Password" sebagai autentifikasi
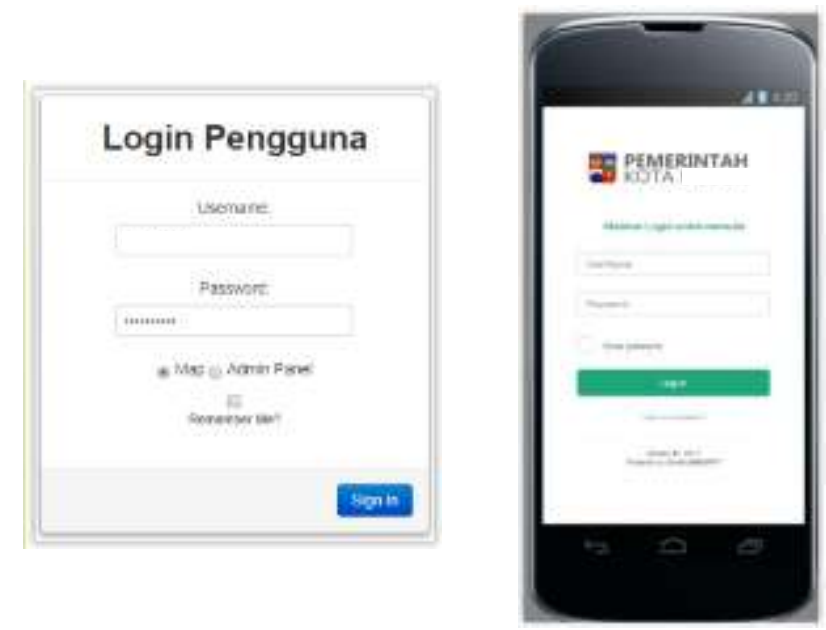

Tampilan halaman awal dari web bangunan gedung bisa dilihat pada gambar dibawah ini

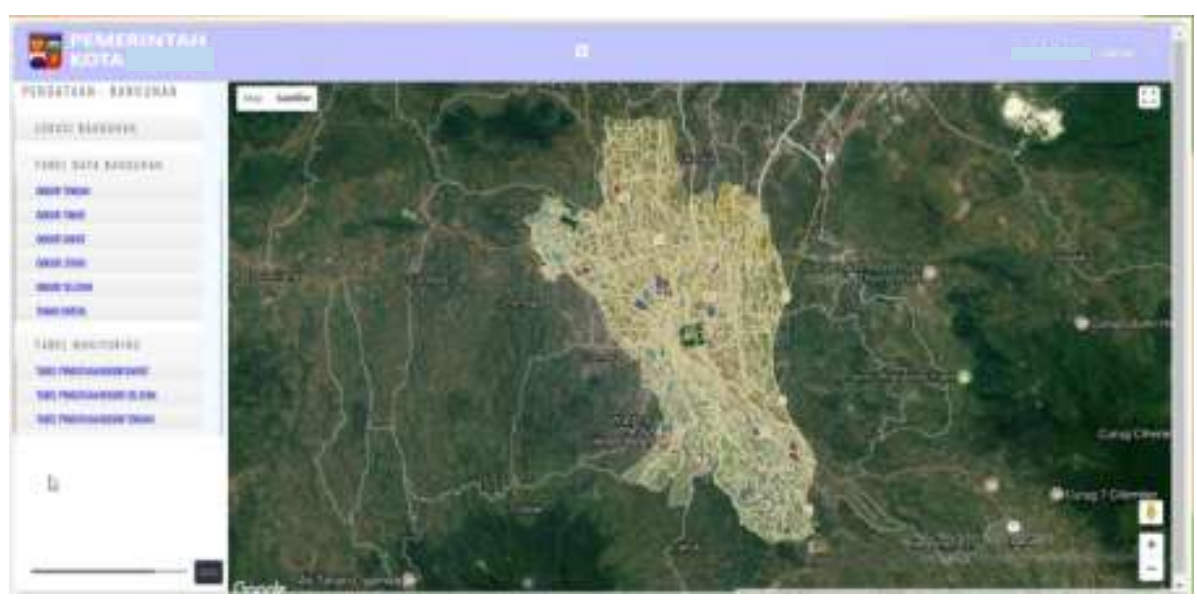

Gambar 10. Tampilan Menu Utama dari halaman web pendataan bangunan gedung 


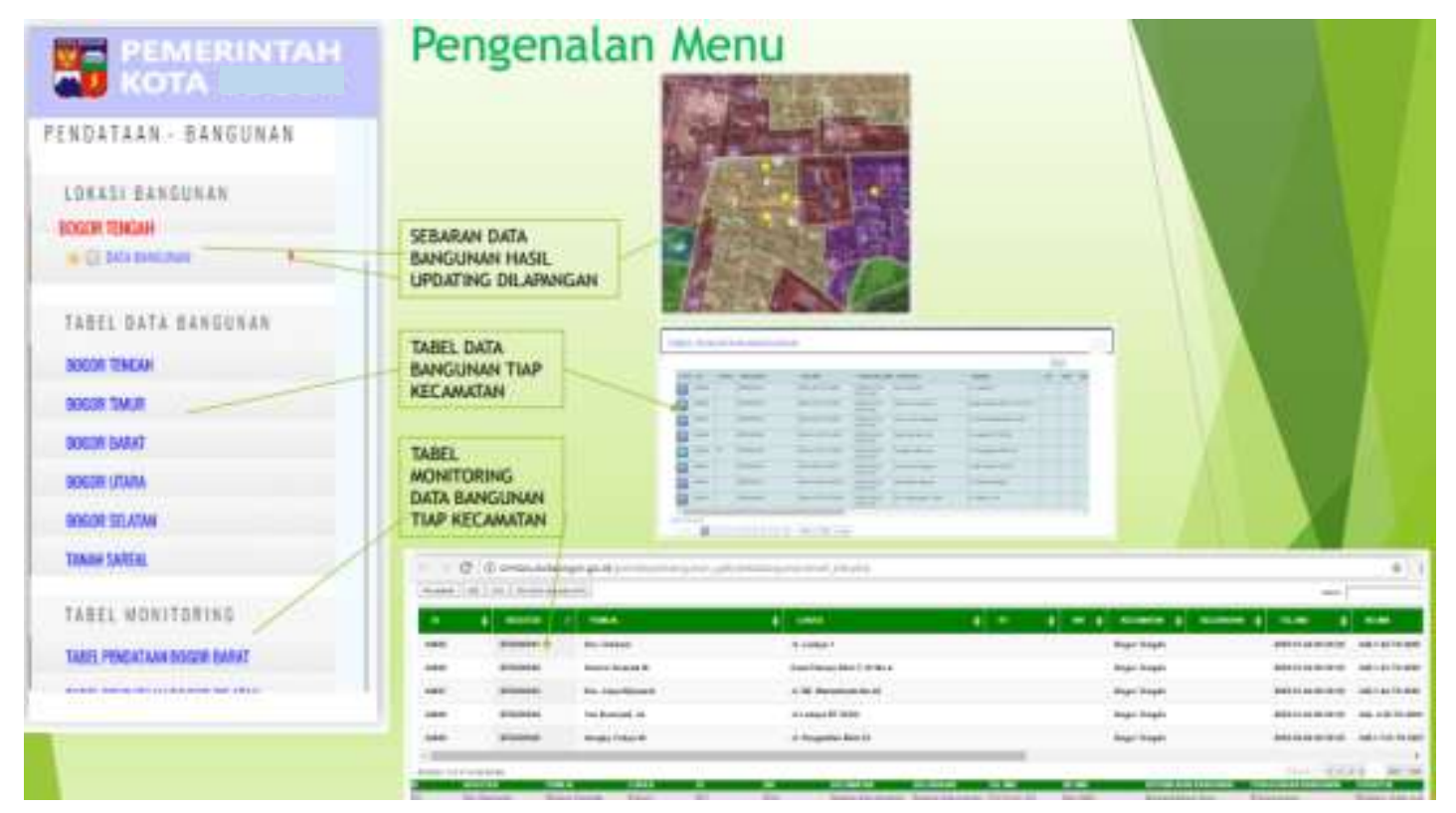

Gambar 11. Pengenalan menu pada web pendataan bangunan gedung

Pada gambar 11 dapat dilihat lokasi bangunan yang terdapat di Kecamatan Bogor Tengah, dimana jika sub menu tersebut dipilih akan menampilkan informasi sebaran data bangunan hasil updating di lapangan.

Sub menu tabel data bangunan menampilkan informasi mengenai tabel data bangunan setiap kecamatan yang ada di kota Bogor. Sub menu tabel monitoring menampilkan informasi data bangunan setiap kecamatan.

Pada kegiatan ini juga dibuat suatu aplikasi mobile menggunakan Android untuk memudahkan pihak surveyor yang ada di lapangan untuk melakukan update atau mengecek data bangunan gedung yang sedang dilakukan proses survey.

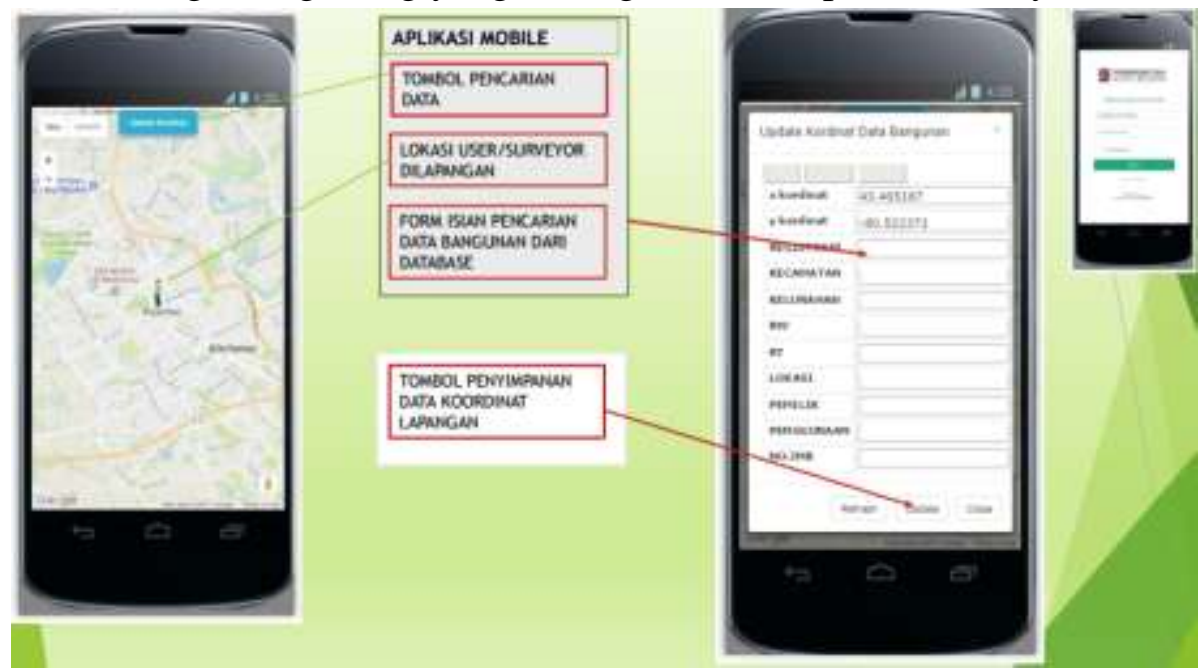

Gambar 12. Aplikasi mobile berbasis Android pendataan bangunan gedung 
Pada gambar 12 dapat dilihat fitur yang terdapat dalam aplikasi mobile berbasis android yang dikembangkan dalam kegiatan ini, seperti fitur tombol pencarian data, fitur informasi lokasi user atau surveyor saat di lapangan, form isian pencarian data bangunan dari database dan tombol penyimpanan data koordinat lapangan.

\section{Penggunaan Desktop dan mobile Updating data bangunan gedung (Team survey)}

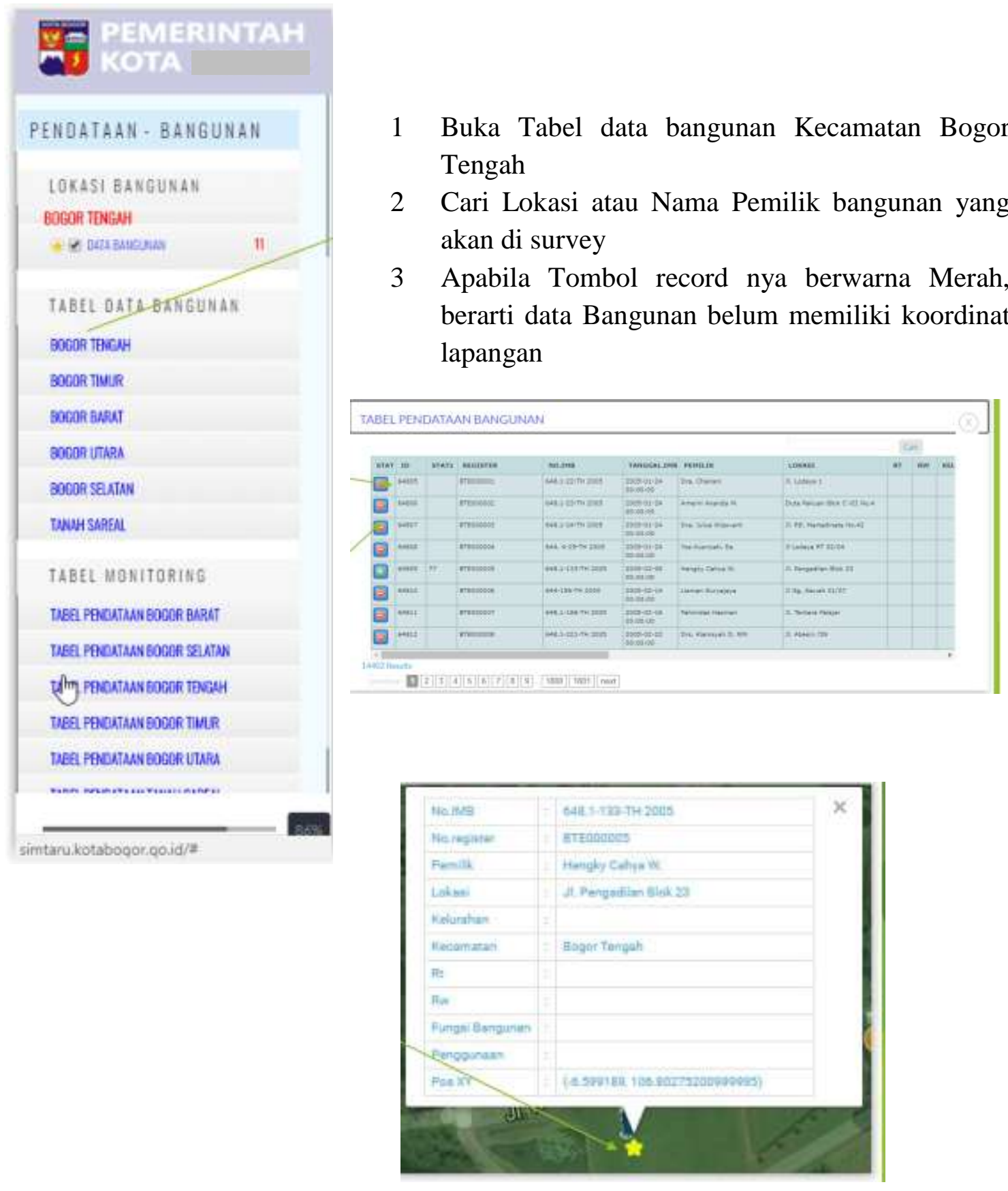

4. Apabila Tombol record berwarna HIJAU, lalu klik, akan menemukan lokasi bangunan, klik Detil, Muncul informasi Data bangunan 
Pada gambar dibawah dapat dilihat informasi mengenai jumlah data bangunan yang terdapat pada kecamatan Bogor Tengah sejumlah 14.402 bangunan gedung.
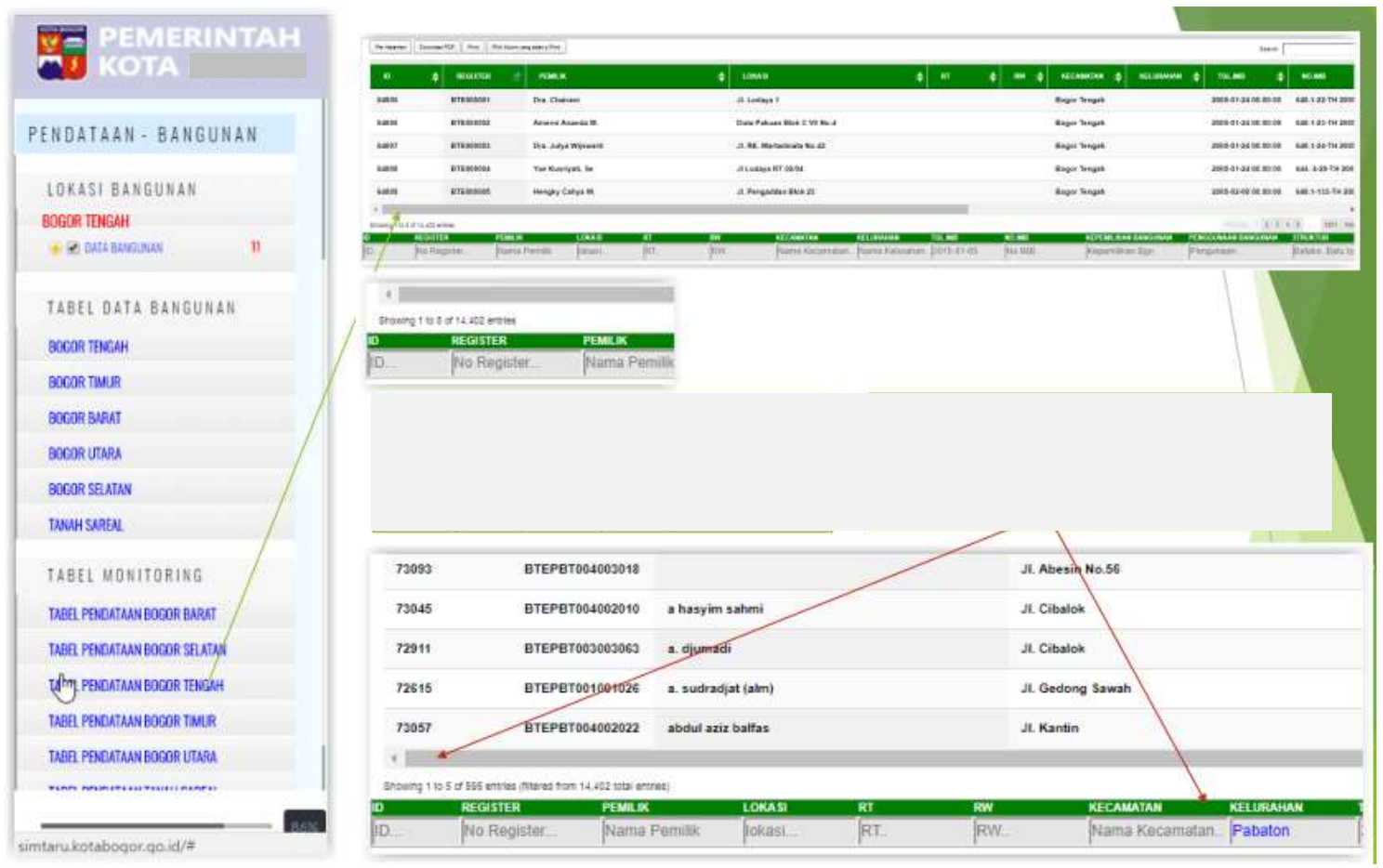

Informasi jumlah bangunan gedung per kelurahan dapat dilihat dengan mengisi nama kelurahan yang akan dilakukan kegiatan survey, dalam contoh gambar diatas kelurahan Pabaton memiliki 595 bangunan gedung.

Data bangunan gedung yang ada di kelurahan Pabaton (seperti dalam contoh) dapat dicetak apabila diperlukan, sebelumnya terlebih dahulu memilih field yang dibutuhkan di lapangan untuk dicetak, yang nantinya informasi tersebut dapat digunakan sebagai data crosscheck di lapangan.

Setelah dilakukan proses filter data lakukan proses unduh dokumen dalam bentuk pdf untuk dilakukan proses cetak

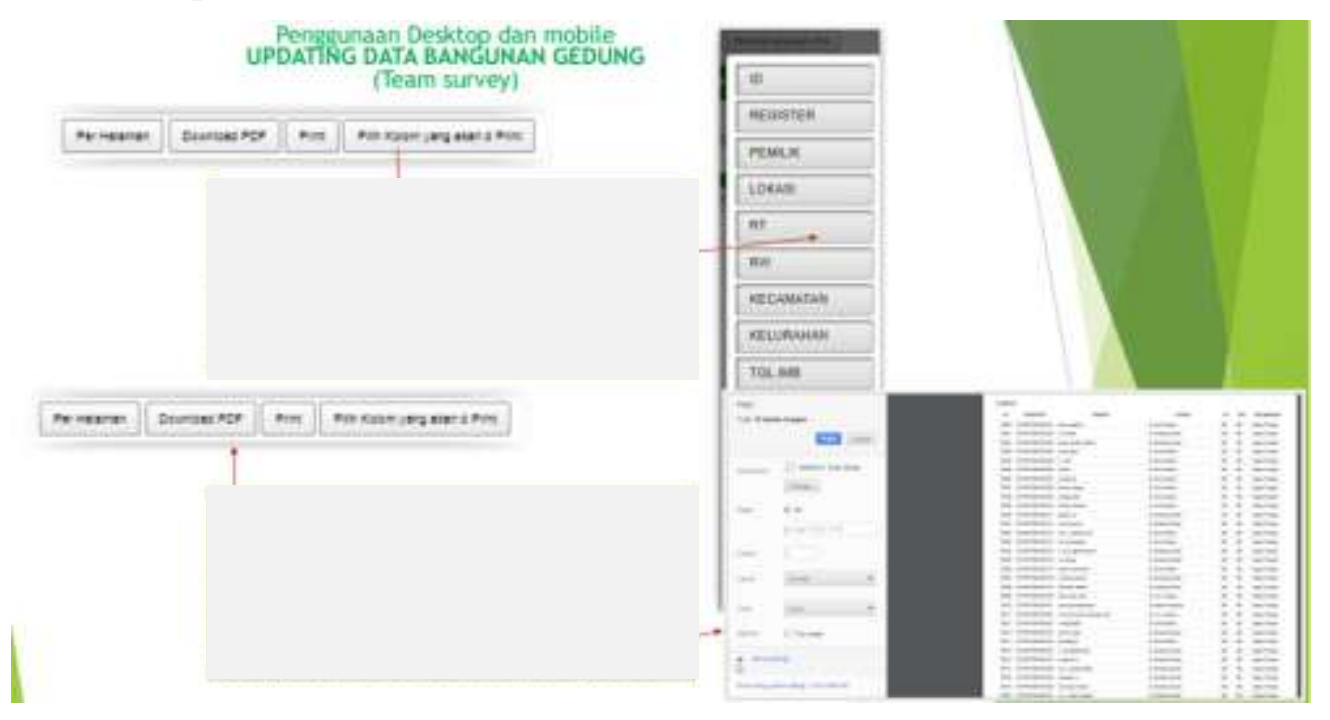


Pada aplikasi mobile berbasis android, dimana dapat dilakukan proses updating data bangunan, proses pemberian koordinat saat sedang melakukan kegiatan survey dapat langsung dilakukan dengan langkah seperti tertera pada gambar dibawah ini
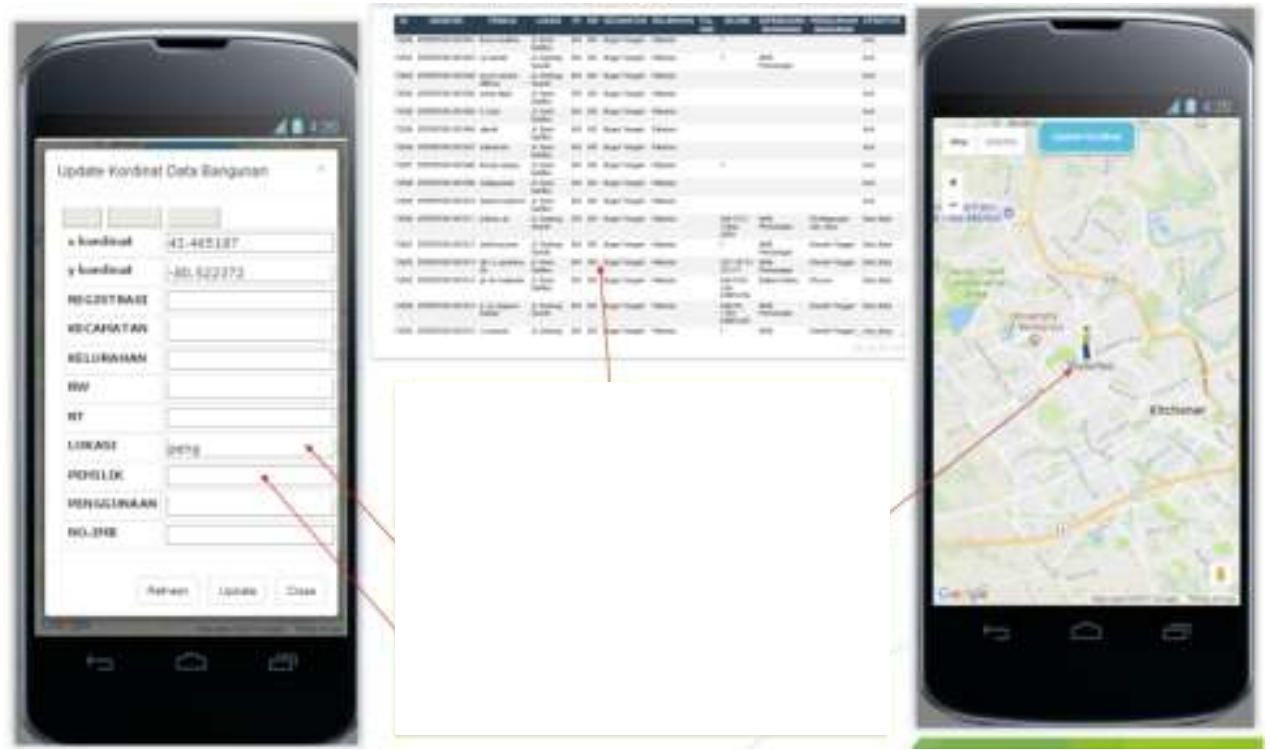

Lakukan pengisian nama jalan yang akan dilacak pada database seperti pada gambar dibawah ini, lalu akan muncul informasi mengenai daftar record selankutnya lakukan pemilihan record yang sesuai, apabila ternyata ada record yang tidak sesuai dengan bukti dilapangan saat dilakukan proses survey maka data dapat dihapus atau dikosongkan, selanjutnya pilih tombol Refresh.

Setelah data ecord terpilih dan sesuai dengan data yang telah sebelumnya dicetak, data field yang kosong harus dilengkapi seperti nomor IMB, Lokasi ( Nomor rumah atau bangunan ), nomor RT/RW, Penggunaan (fungsi bangunan).

Apabila semua data telah lengkap terisi dan tidak ada yang salah maka tekan tombol Update, selanjutnya dilakukan hal yang sama untuk setiap lokasi bangunan.
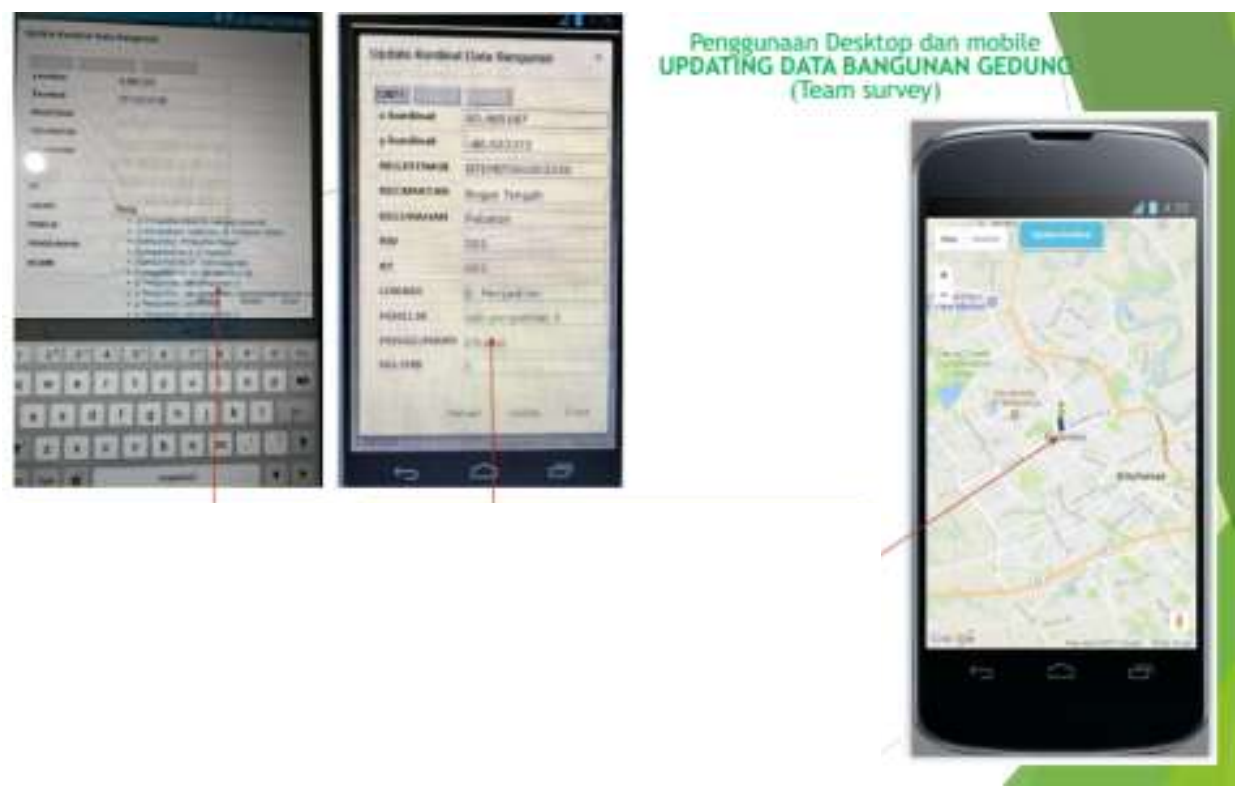
Proses Crosscheck data hasil updating koordinat lokasi bangunan di lapangan dapat dilakukan proses monitoring pada aplikasi berbasis desktop.

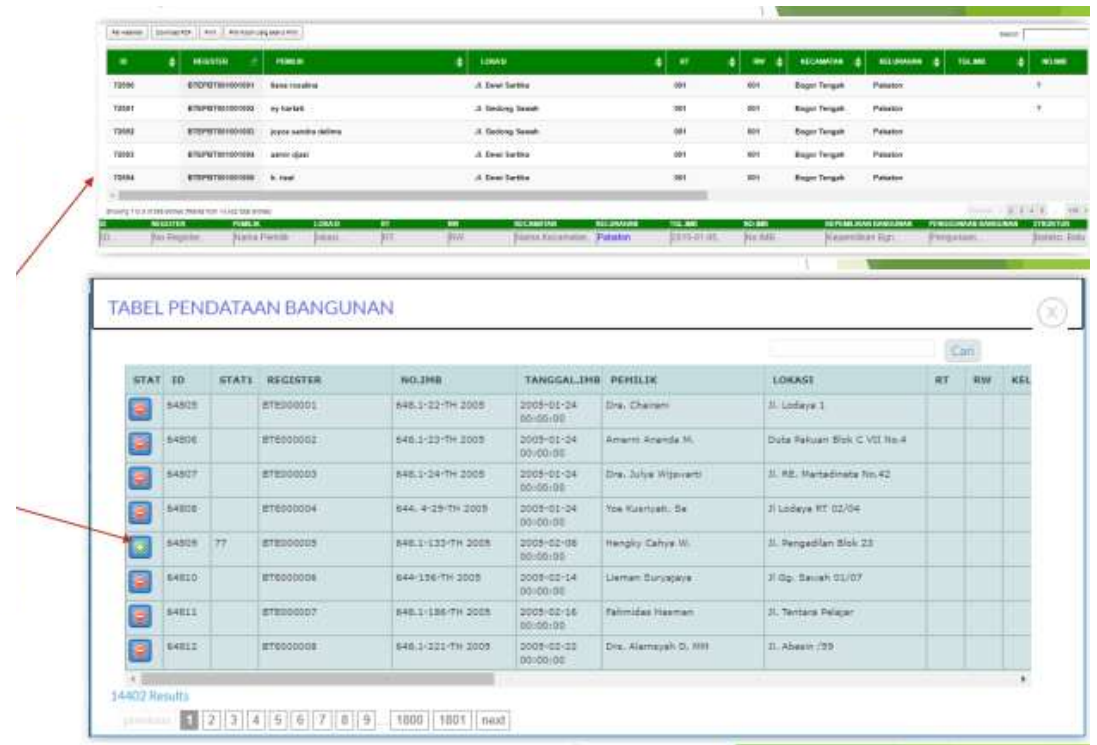

Pada tabel data bangunan seperti pada contoh sebelumnya yaitu Kecamatan Bogor Tengah, terlihat warna tombol merah pada tiap record data bangunan yang telah diupdate koordinat lokasi bangunannya. Tombol akan berubah menjadi Hijau dan tabel monitoring record akan terisi koordinat yang telah diupdate di lapangan

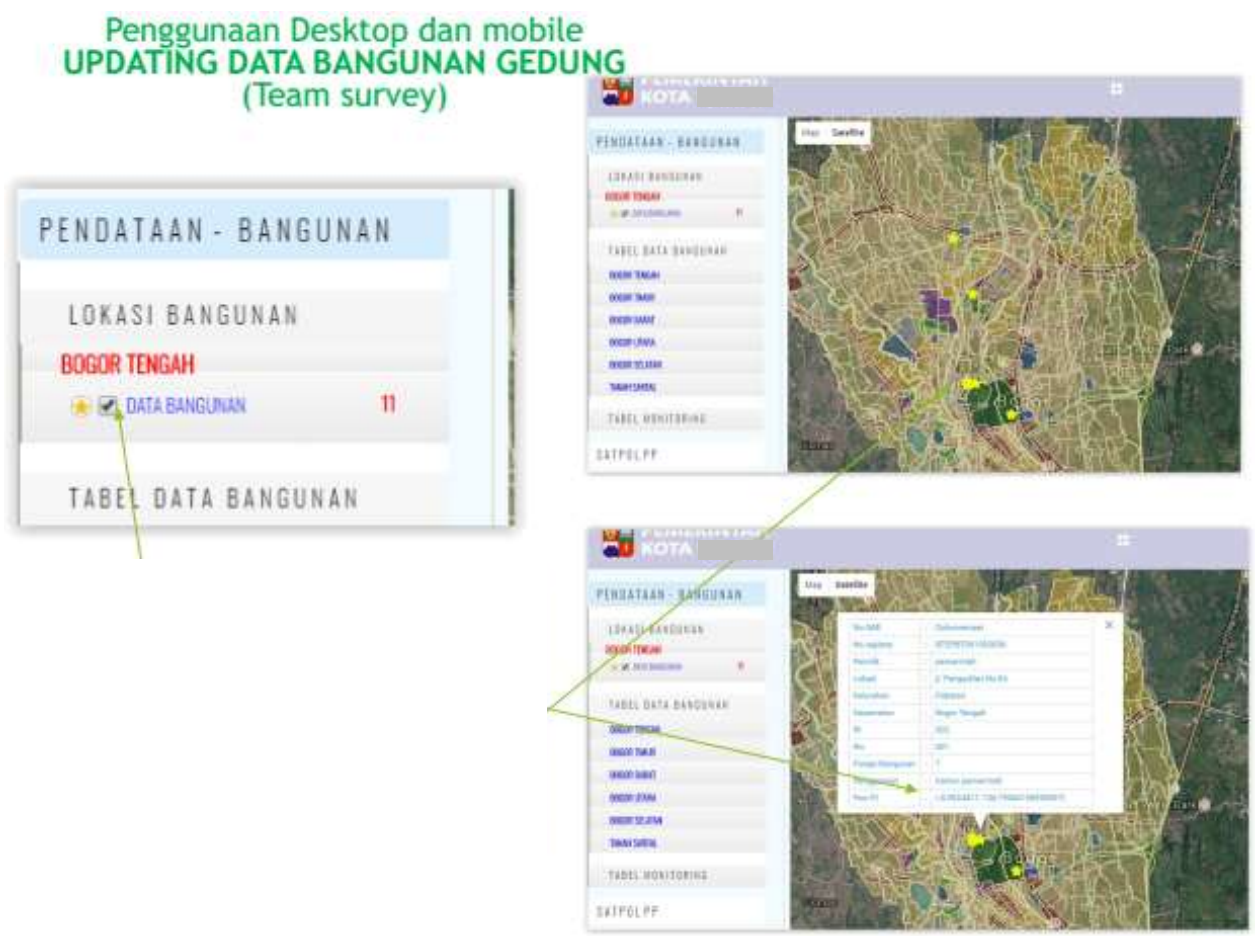




\section{Kesimpulan dan Saran}

Sesuai dengan hasil analisa dan pembahasan yang telah dijabarkan pada pekerjaan ini, beberapa kesimpulan dapat diambil, sebagai berikut :

1. Kegiatan Updating database bangunan gedung yang telah dilakukan dapat meningkatkan kualitas kinerja operasional pengawasan dan pengendalian bangunan di Kota Bogor sehingga terwujud tertib penyelenggaraan bangunan sesuai amanat Peraturan Daerah Kota Bogor Nomor 7 Tahun 2006 tentang Bangunan Gedung dan Peraturan Daerah Kota Bogor Nomor 8 Tahun 2011 tentang RTRW Kota Bogor 20112031.

2. Memberikan kemudahan untuk mengakses data/informasi terkait penyelenggaraan bangunan gedung di Kota Bogor baik oleh pihak internal maupun eksternal

3. Hasil update database bangunan gedung memudahkan bagian terkait dalam hal membuat laporan-laporan, karena telah terformat dan terstruktur secara dinamis.

Berdasarkan kesimpulan di atas dapat diambil beberapa rekomendasi sebagai indikasi tidak lanjut yang harus dilakukan dalam rangka kegiatan updating database bangunan gedung Kota Bogor. Beberapa saran meliputi:

1. Perlu diperhatikan terkait operasional penggunaan program aplikasi Android dan kegiatan updating database bangunan gedung yaitu aspek keamanan dan pertanggungjawaban data dari perangkat lunak ini terutama oleh pihak surveyor. Pihak yang berwenang harus memperhatikan beberapa faktor dan pertimbangan sebelum memberikan izin penggunaan perangkat lunak ini kepada pengguna (user).

2. Adanya SDM yang mempunyai keahlian dibidang IT dibutuhkan untuk mendukung penggunaan sistem dan teknologi informasi terutama di daerah sangat diperlukan. Oleh karena itu sebaiknya mulai dipikirkan mekanisme untuk menyediakan SDM di bidang IT untuk membantu penggunaan aplikasi android dan update database bangunan gedung ini

\section{Daftar Pustaka :}

[1] Peraturan Menteri Pekerjaan Umum Nomor 17/PRT/M/2010 tentang Pedoman Teknis Pendataan Bangunan Gedung di Kota Bogor

[2] Peraturan Daerah Kota Bogor Nomor 7 Tahun 2006 tentang Bangunan Gedung dan Peraturan Daerah Kota Bogor

[3] Peraturan Daerah Kota Bogor Nomor 8 Tahun 2011 tentang RTRW Kota Bogor 2011-2031. 